\title{
Amenity as educator: geographies of education, citizenship, and the CPRE in 1930s England
}

Article

Accepted Version

Church, F. (2019) Amenity as educator: geographies of education, citizenship, and the CPRE in 1930s England. The Geographical Journal, 185 (3). pp. 258-267. ISSN 1475-4959 doi: https://doi.org/10.1111/geoj.12279 Available at https://centaur.reading.ac.uk/80891/

It is advisable to refer to the publisher's version if you intend to cite from the work. See Guidance on citing.

To link to this article DOI: http://dx.doi.org/10.1111/geoj.12279

Publisher: Royal Geographical Society

All outputs in CentAUR are protected by Intellectual Property Rights law, including copyright law. Copyright and IPR is retained by the creators or other copyright holders. Terms and conditions for use of this material are defined in the End User Agreement.

$\underline{\text { www.reading.ac.uk/centaur }}$ 
Central Archive at the University of Reading

Reading's research outputs online 


\section{Amenity as Educator: Geographies of Education, Citizenship, and the CPRE in 1930s England}

\section{INTRODUCTION}

The Council for the Preservation of Rural England (CPRE) was founded in 1926 as a voluntary, preservationist, and umbrella organisation seeking to organise 'concerted action' to protect rural amenity, 'to act either directly or through its constituent and affiliated members as a centre for furnishing or procuring advice and information upon any matters affecting the protection of such amenities', and importantly, 'to arouse, form and educate public opinion in order to ensure the promotion of the objects of the Council' (CPRE, 1926-30). The CPRE still exists today, though its acronym now stands for the Campaign to Protect Rural England. Whilst much work has examined interwar preservationism and the CPRE's focus on planning legislation and design (Bunce, 1994; Matless, 2016, 1997, 1993, 1990; Murray, 2010; Reynolds, 2016) less attention has been paid to the CPRE's cultures of education for children and young people. This paper explores the spaces and practices of (in)formal education and learning by considering the educational cultures of the CPRE in 1930s England. Drawing on archival research, the paper also contributes to cultural-historical geographies of preservationism, and speaks to themes of citizenship, authority, voluntarism, futurity, and childhood. Recent calls for further work on (in)formal education (Holloway and Jöns, 2012) and the relationships between education, volunteering, and society (Mills, 2014) mean that this paper's original contribution to geographies of education is timely.

The paper makes three key contributions. Firstly, it argues that the CPRE understood amenity as both education and educator. This article demonstrates that for the CPRE, amenity was understood as a cultural assessment and a critical way of reading the landscape, informed by sets of (embodied) knowledges associated with notions of beauty, character, and experience. Amenity was mobilised 
by the CPRE to offer an experiential and intuitive education in preservationism for children and young people across informal and formal spaces and practices. Secondly, this paper argues that this education in preservationism was bound up with ideas of (future) citizenship, hope, and (future) preservationism: an education that would remain with the child into adulthood. Thirdly, in considering geographies of (in)formal education, this paper explores notions of the CPRE's authority, demonstrating that it was not inherent, but was instead complex, precarious, and continuously requiring (re-)negotiation. The article begins by positioning itself amongst existing academic literature, then considers two educational topics, namely nature study and school design, through an examination of the CPRE's archival material. It then brings these themes together in a conclusion, with suggestions for further study.

\section{GEOGRAPHIES OF EDUCATION AND CHILDHOOD}

\subsection{Education and Educators: Schools and Nature}

This paper draws together literature on (in)formal education, the spatiality and materiality of school buildings, forms of educators, and nature. Recent work on the geographies of education has explored the spaces, materials, and practices of (in)formal education for children and young people (Cartwright, 2012; Holloway and Jöns, 2012; Mills and Kraftl, 2014) as being important in an understanding of how childhood is variously constructed (Kraftl, 2006), as well as the often complex and fluid boundaries of education and training (Bauer and Landolt, 2018; Mills, 2014). By considering aesthetics alongside the materiality of childhood spaces and education, 'aesthetic practice retains a more embodied, corporeal register', its appreciation linked to a 'sensory experience of bodily perception' rather than a 'disembodied act of judgement' (Kozlovsky, 2016: 6), drawing on symbolic meaning and representation (Cosgrove and Daniels, 1988) whilst also considering practice and performance (Thrift and Dewsbury, 2000). In so doing, schools can be understood as spaces 
which 'in their materiality, project a system of values', with meaning made through use and experience (Burke and Grosvenor, 2008: 8).

This focus on the spatiality and materiality of education has allowed academics to explore various forms of pedagogy, and educators (Burke, 2005; Grosvenor, 2005) such as school buildings (Kozlovsky, 2010) that can become in essence a 'third educator' (Kemnitz, 2005: 605). The countryside (Gruffudd, 1996; Matless, 2016; Ploszajska, 1998) and nature (Ferretti, 2016) have also been understood as educators, though of course not all natures are understood as desirable learning spaces (Kraftl, 2013). Here, nature is understood as 'fluid, complex, and emergent from situated interactions and interconnections' (Lorimer, 2008: 2047). In this 'togetherness' nature and culture are bound together through landscape and place (Cloke and Jones, 2001: 651). This paper builds and expands on these sets of literature to argue that for the CPRE, amenity was both education and educator. Understood as a cultural assessment and critical appraisal that is temporally and spatially situated (Park and Coppack, 1994), 'amenity' was mobilised by the CPRE to provide an education in preservationism for children and young people across informal and formal spaces and practices.

\subsection{Childhood: Citizenship, Futurity, and Hope}

Recent literature has explored the geographies of childhood in relation to rights and responsibilities (Robinson and Mills, 2012) connecting present and future practices of citizenship (Mills, 2013), whilst historical geographers have studied the connections between childhood and education to explore themes of nationhood, citizenship, futurity and morality (Gagen, 2004; Ploszajska, 1994). Important in discussions of childhood and the future is the notion of hoping, where a following generation is viewed as the answer to future societal issues (Kraftl, 2012) producing 'an affective logic of hope' (Kraftl, 2006: 82-3), that can be understood as an 'accumulation strategy' (Katz, 2008: 10). Education, childhood, and the future of the nation are thus seen to be inextricably connected 
(Hulme, 2015). Here literatures on citizenship, moral geographies, futurity and hope, are combined, and the paper expands on this work to argue that for the CPRE, children and young people educated in appreciating amenity and understood as future citizens, would be able to solve succeeding issues regarding countryside protection as future preservationists.

This article is also informed by exploratory archival fieldwork (Bailey et al., 2009; Parrish, 2010) using the CPRE collection held at the Museum of English Rural Life (Reading), turning to materials such as pamphlets, reports, correspondence, minutes, and photographs, from the 1930s. Drawing on the Council's original objectives (see above), the materials were analysed with regards to the theme of amenity, and with the emerging research themes of (in)formal education, futurity, and citizenship. Additional material was consulted (Elena et al., 2010) in relation to these themes and period through the online archives of The Times and the Spectator.

\section{NATURE STUDY}

The Wild Plant Conservation Board (WPCB) was formed as an 'integral part' of the CPRE in November 1931 (CPRE, 1937). The list of organisations represented on the Board was a 'formidable one' (Milne-Redhead, 1971: 198) including the Royal Botanic Gardens at Kew, the Royal Horticultural Society, the Trustees of the British Museum (Natural History), the Council for the Preservation of Rural Wales (CPRW), the National Trust, Flora's League, the Men of the Trees, the School Nature Study Union (SNSU) and the British Ecological Society, among others (CPRE, 1937). Existing literature has focused on the Board's legislative endeavours, arguing that the WPCB achieved little, having worked on the drafting of a private bill which received scant support (Milne-Redhead, 1971; Sutcliffe, 2009). However Allen acknowledges that the WPCB carried out 'useful work of a mostly low-level, educational sort' (1987: 210). Education was in fact a significant part of the Board's work, with legislation seen as secondary and less effective. The Times reported that 'after 
an examination of the whole problem the board has reached the conclusion that it is through the medium of education rather than drastic legislation that a solution is to be reached' (1933) and as such the Board's focus would be 'concentrated on educational work' (CPRE, 1937). W. Beach Thomas wrote in the Spectator of the WPCB's inception under the CPRE, 'they see that you cannot save the soul of the country by legislation' (1933: 14).

The Board's approach to nature education for children and young people can be explored through two key documents: first, a 1931 report compiled by the Board based on the responses to a questionnaire sent out to each of its constituent bodies; and second, the WPCB's pamphlet entitled The Protection of Wild Flowers, published in 1932 by the CPRE (republished in 1937). Composed by Professor F.E. Weiss and Professor E.J. Salisbury (Presidents of the Linnean Society and the British Ecological Society respectively) the pamphlet was designed 'not only for general use but especially for circulation in educational establishments throughout the country' (The Times, 1933). Taken together, these documents provide an insight into the approaches to education undertaken and suggested by the CPRE, WPCB, and (through constituent membership) the leading ecological, conservation, and amenity societies, in England during the 1930s.

In the first half of the twentieth century, schools provided a space for nature study (Gruffudd, 1996; Robinson and Mills, 2012). The planner and educator Patrick Geddes proposed that 'experiential learning' was arguably more beneficial than education through the 'rigidities of the classroom' (Gruffudd, 1996: 415). The modern school was 'no longer a monastic institution walled off from the life around it, it has responsibility to that life, and derives its strength from it' (CPRE, 1935). The WPCB encouraged teachers to take pupils out 'into the field' that they might appreciate 'plants as more interesting and attractive when growing, than as specimens in vases or as dried in a herbarium' (CPRE, 1937). Examining plants and their habitats would provide the pupils with an understanding of the seasons and the plants' 'life histories' by 'using as illustrations species which are 
characteristic of definite communities and which ... exhibit features that manifestly fit them for their particular niche in Nature', elements that could not be recognised 'when the plant is removed from its natural environment' (CPRE, 1937). Nature study emphasised the importance, and resulting harmony, of the plants remaining in their 'natural surroundings' (WPCB, 1931). This appropriate geography (Matless, 1993) could guide the child from interest and knowledge to emotional engagement. The conservation society Flora's League, founded in 1925 by Sir Maurice Abbott-Anderson (Allen, 1987; Milne-Redhead, 1971), maintained that 'a great fund of knowledge as to the behaviours of plants can be amassed by living in intimate contact with wild plants, and by being in the position to watch them day by day' (WPCB, 1931). Moreover, 'the greater the knowledge of children with regard to living things the greater their appreciation for them' (WPCB, 1931). This emphasis on the primacy of knowledge was key: 'the sentiment must follow the understanding' (CPRE, 1935: 22) as the 'desire to keep anything will only follow the feeling that the thing is worth keeping. It is of little avail to tell a child that the country is beautiful; he must be led to feel for himself that it is. And this must follow the stages, first, of interest in, then, appreciation of, and finally affection for the countryside' (CPRE, 1936a: 31, original emphasis). Comprehension would be followed by a love of nature, as would the instinct and action to care for nature.

Nature study provided the dual 'opportunity for the development of interest and the power of observation' (CPRE, 1937) providing knowledges that could only be gained through amenity and being in-place. Observation is therefore a specific skill, drawing on other competencies and enabling the observer to critically view and engage with their surroundings (Robinson and Mills, 2012). Patrick Abercrombie (the CPRE's Honorary Secretary and co-founder) maintained that 'it should be possible in a given scene to determine wherein its special characters and beauty consists...there must be, in a word, some sort of assessment of values...in what consists the special quality for which it is valuable' (1945: 196 emphasis added). Training in observation would mean a new way of seeing and being. In viewing trees and flowers, children would no longer take them for granted or see them 
'casually' (CPRE, 1936a: 31). Indeed, Flora's League linked together these notions of observation and skill, arguing that through nature study 'the young are taught to observe and to deduce from their observations' and thus 'the irrepressible collector is admonished, and a love of Nature is promoted' (WPCB, 1931 emphasis added).

Figure 1, taken from a folder of photographs of various flora and fauna (often collected by both the CPRE's national and local offices) is concerned with the issue of the 'irrepressible collector'. The photograph is specifically (Rose, 2000) and critically read by the CPRE (Brace, 2003) to demonstrate the almost aggressive act of picking wildflowers, captioned on the reverse as 'after a bluebell raid'. The 'collecting instinct' that led to such 'raids' could also be tackled by understanding the importance of materiality in a child's perception of and interaction with nature. An 'antidote' to the collecting instinct (CPRE, 1937) and thoughtlessness (WPCB, 1931) associated with the non-citizenly picking of wildflowers (Matless, 2016), was to encourage pupils to collect and preserve common plants and illustrate these specimens with details of the plant's habitat and life cycle. Collecting might even be put to good use as 'many weeds, such as the Nettle, Coltsfoot, Bishop's Weed, Horsetail Fern, Creeping Buttercup, Shepherd's Purse, Creeping Thistle, exhibit a large number of very interesting features and their collection would be beneficial rather than the reverse' (CPRE, 1937). These embodied knowledges of observation, collection, and notation were shaped by moral geographies of preservationism, that regulated conduct (Driver, 1988; Matless, 1997) of 'behaviours and bodies' (Robinson and Mills, 2012: 23). Through undertaking practices associated with preservationism, children would learn how to 'conduct themselves towards the beauties of the countryside, and also how they should not conduct themselves' (WPCB, 1931 original emphasis).

Importantly, Kozlovsky has highlighted the need to consider the ambivalent nature of children's citizenship (2010), a point explored further by Mills through the notion of 'citizens-in-the-making', 
where children and young people were simultaneously preparing for future citizenry and performing present practices of citizenship (2013). Here this tension is demonstrated through the practices of nature study, education in amenity, and moral geographies of preservationism, juxtaposed against developing 'the attitude of the coming generation on these matters' as 'citizens of the future' (WPCB, 1931). Thus geographies of the past, present, and future were linked through the practices and hoped for future-practices of children: 'education will prove in the long run by far the most effective means of safeguarding our flora' (WPCB, 1931). As the ecologist and co-author of the WPCB's 1932 pamphlet, E.J. Salisbury, noted 'the present always depends upon the past, and the community of today is, at least in part, the consequence of the community of yesterday' (1932, cited by Sheail, 1982: 139).

As this paper has revealed, the CPRE and WPCB wanted education in nature study to be provided through formal educational structures and organisations such as the curriculum and the Board of Education (as well as County Education Authorities, Universities, or Training Colleges) (WPCB, 1931). In particular, teachers could 'do a great deal to inculcate the spirit of preservation and to further the idea of guardianship of the flowers of the countryside' (CPRE, 1937), and it was important that 'teachers themselves should be properly informed' (WPCB 1931). G.F. Herbert Smith, the WPCB's Chairman, noted that the Board was 'fully alive to the necessity of educating the teachers' (1932). Certainly the CPRE had 'already prepared lessons to guide teachers in their work amongst children' (Spectator, 1931: 6). In providing school teachers with the knowledge necessary to guide nature study, informal education on preservation was translated through formal educational structures, providing the CPRE's preservationism with the authority of formal educational spaces, practices, and identities.

Indeed extant literature has positioned the CPRE as an organisation wishing to "claim a clear and absolute authority over landscape' (Matless, 2016: 46), through an arguably technocratic approach 
(Woods, 2005). The theme of authority has been explored in relation to the CPRE through studies on regional development (Dehaene, 2005) and preservationist discourse (Murray, 2010). For Matless, preservationists provided leadership, impetus, and an abundance of 'self-belief and presumed authority' (2016: 46). However, this present paper argues that for the Council, authority was not inherent, but complex and precarious, continuously being (re-)negotiated through a variety of spaces, identities, and practices. The WPCB and CPRE were aware of this precarity, and that without working through formal educational spaces and structures 'schools would become the happy hunting ground of an army of cranks and faddists if every well-meaning society was allowed right of entry into them' (WPCB, 1931: 25). Thus issues of legitimacy (Allen, 2003; Bulkeley, 2012) were important. Sir Henry Richards (former Chief Inspector of the Board of Education) speaking at the CPRE's eighth national conference in 1935 maintained that the Council was 'right to be hypersensitive on any tendency to use our schools for propaganda', as in his experience 'every 'cause' with a big 'C' tends to run to the schools for help' (CPRE, 1935). Nevertheless Richards argued that education in preservationism through nature study was both 'formative and educational', and 'no education given in these schools is complete or sound which ignores the power and opportunities given by environment' (1935). Thus formal education, in its spaces, structures, and materiality, provided the CPRE (and informal education in preservationism) with legitimacy and authority.

\section{SCHOOL DESIGN}

The second educational topic considered here is school design. In exploring this aspect of the CPRE's cultures of education alongside nature study, this paper demonstrates the way in which amenity, as a concept, was mobilised across a variety of educational spaces and practices. School building during the 1920s and early 1930s was both shaped and stunted by a poor economy (Seaborne and Lowe, 1977), and the recommendations of the 1925 Baines Committee to build cheaply (though its report was never published) highly influenced the Board of Education in the following 
years (Harwood, 2010). It was not until the mid-1930s that opportunities for development were briefly animated, when in 1936 the Board of Education announced a return to a $50 \%$ grant on new school buildings, having been just 20\% since 1931 (Seaborne and Lowe, 1977). With the Government's recent focus on education, in raising the school age and organising schools, the CPRE noted that this 'afforded a good opportunity for further approach to the Board' (CPRE, 1936b: 14), particularly as 'the responsibility of the Board of Education in relation to public architecture of the country has been insufficiently recognised in the past' (CPRE, 1936c: 13). Burke and Grosvenor note that 'reading' a school in a landscape is not difficult' as they are 'quickly placed and are rarely confused with anything else' (2008: 7). Their ubiquity and identifiability meant that schools had a great 'influence upon the amenity of the countryside and the decorous development of village life' (CPRE, 1936c: 13).

For the CPRE, the amenity of schools and their setting also had a great influence on education itself. The Council argued that 'the elevation, that is to say the actual appearance of the school, is in itself important to the child on educational grounds' (CPRE, 1936c: 12). This was done by setting an aesthetic example, which would stay with the child forever. Just as Post Office buildings had set 'a standard of excellence' (CPRE, 1936c: 13), the school 'structure which earns well-informed praise will in due course impress itself on the adolescent mind, and will be an example of fitness which the child will never forget and which will afterwards serve as a standard of appreciation' (1936c: 12). This followed the existing educational approach of extrapolating from the known to the unknown (Ploszajska, 1998) and thus through an experiential education, knowledge becomes both a means of comparison and a point of reference for wider evaluation (Maddrell, 1998).

In February 1936, the CPRE wrote to the Board of Education on the matter of school design. In reply, the Board noted that they were 'in sympathy' with the Council, however they highlighted the difficulty of questioning plans submitted to the Board 'on aesthetic grounds' without the Board's 
architects having an 'exact knowledge of the locality and appearance and lay-out of the school site' thus they suggested that the CPRE approach each Local Authority about specific developments (Pelham, 1936). In this case however the CPRE were not concerned with singling out and critiquing specific designs. Lord Crawford (the CPRE's President) argued that there was in fact 'every objection to doing this, because we should have to assume that the local man is inefficient, instead of operating by means of a circular letter which assumes that it is the other county which is wrong' (Crawford, 1936). On the advice of Lord Crawford, Griffin wrote to the Board of Education enjoining the Board to 'take a more direct responsibility' (1936). Though the Board declined to issue a circular, they were happy to include some of the CPRE's key points, writing that 'so long as we have the [CPRE's] material I do not think there will be much difficulty in shaking it up into a form which will fit in with the new Suggestions' (Savage, 1936). The Suggestions for the Planning of Buildings for Public Elementary Schools was published in 1937 and contained 'a special section dealing with architectural and aesthetic considerations' (CPRE, 1936d: 9).

Regarding layout, the Board in their Suggestions noted that the Architect was free to 'plan in forms of almost endless variety, but he will allow the conditions of the site to direct him'; this was predominantly focused on the topography and aspect of the school site (1937: 75). Yet Seaborne and Lowe point out that economic constraints meant that in practice 'architects responded with a dull uniformity...from which few buildings escaped' (1977: 121). Nevertheless, the Board's recommendations emphasised the need for site-specific planning, echoing the CPRE's argument for well-designed schools 'set within suitable surroundings and planned, so far as circumstances permit, with good local knowledge' (CPRE, 1936c: 12-13). Thus the Board contended that 'whether any particular type of plan can be recommended as being generally the most suitable is doubtful. It can, however, be said with certainty that no type will fit every case' and so the architect must 'allow the conditions of the site to direct him' (Board of Education, 1937: 75). 
Viewing the school in relation to its setting, and as part of the wider landscape, was a key concern for the CPRE, as 'for the preservation of amenities in the English Countryside it is important that no disruptive note should be produced by any building or group of buildings' (Griffin, 1936). This need for harmony was noted by the Board when it stated: 'that schools should be attractive features in the architectural layout of a neighbourhood, in harmony with their surroundings, is obviously desirable' (Board of Education, 1937: 81). One way of promoting harmony was to avoid 'any attempt to imitate a specific "period style"" (Griffin, 1936). Such a dislike of mock, bogus, or sham buildings (as opposed to architectural integrity) was a key preservationist trope (Matless, 1990). The CPRE linked the embellishments and beautification associated with these dishonest buildings with costly extravagance, "where a building is pretentious, and where "decorative features" are accumulated to give importance to the elevation, the costliness increases as the design deteriorates' (CPRE, 1936c: 13). The Board was mindful of costs, noting that 'where traditional methods of building are continued' it expected 'such economies as experience has shown can be effected' (1937: 85). Suggested low cost alternatives included Empire timber for framing, external wall coverings, or floor boarding due to the relatively low cost in upkeep (1937: 83). The CPRE was aware of this need to economise, suggesting that costly materials could be substituted for cheaper alternatives of a similar colour or shade that would be in keeping with the landscape: "if the extensive use of stone is too expensive then sandfaced rustic brick might be used, as this would not be out of harmony in a stone country' (Griffin, 1936). Amenity, through harmony, integrity, and localism, embodied in the spatiality and materiality of the school, provided an education, becoming 'in itself an instrument of definite and distinct educational value' (CPRE, 1936c: 12-13).

\section{CONCLUSION}

In considering the educational cultures of the CPRE in 1930s England, this paper has made an original contribution to geographies of education. In exploring the (in)formal spaces and practices of the 
CPRE's cultures of education, this article has contributed to debates on childhood, and demonstrated the ways in which the CPRE mobilised amenity to provide an education in preservationism, that connected with themes of hope and futurity through citizenship. Education of and from amenity, would provide children and young people with a standard of appreciation and an aesthetic (in its broadest sense) framework which could be applied at a variety of scales, spaces, and temporalities: an education that would remain with them throughout their life. Future citizens could also become future preservationists.

This paper has shown amenity to be a key consideration for the CPRE: a cultural assessment or appraisal drawing together notions of harmony, care, beauty, architectural honesty, local knowledge and character, that were shaped by appropriate and moral geographies of preservationism. For the CPRE, these knowledges could be learnt through an experiential or intuitive education, with meaning drawn from the amenity of (natural) physical environments, through a variety of spaces, materials, and practices: amenity was both education and educator. Amenity is therefore relational, contextual, and complex. In encapsulating ways of viewing and being-in nature, and extending to questions of (future) citizenship, preservationism, voluntarism, and education, amenity delineates the 'proper' relations between people, environment, and practices. There is scope for further examination of amenity within historical and contemporary geographies of (in)formal and outdoor education, in identifying not only the spaces, materials and practices that are deemed educational, but also in exploring the ways in which they become educational.

Lastly, in tracing the CPRE's engagement with (in)formal spaces, practices, and structures of education, this paper has argued that for the CPRE, authority was both complex and precarious, requiring continuous (re-)negotiation (a nexus that requires further study), and revealed the ways in which it drew on other forms of authority and legitimacy, thus contributing to ongoing academic debates within Geography and beyond on the complex and fluid boundaries of (in)formal education. 


\section{REFERENCES}

Abercrombie, P. (1945). Town and Country Planning. (2nd ed.) London: Oxford University Press.

Allen, J. (2003) Lost Geographies of Power. Oxford: Blackwell.

Allen, D. E. (1987). Changing attitudes to nature conservation: the botanical perspective. Biological Journal of the Linnean Society, 32, 203-212. doi:10.1111/j.1095-8312.1987.tb00427.x.

Bailey, A. R., Brace, C., \& Harvey, D. C. (2009) Three geographers in an archive: positions, predilections and passing comment on transient lives. Transactions of the Institute of British Geographers, 34, 254-269. doi:10.1111/j.1475-5661.2008.00334.x.

Bauer, I., \& Landolt, S. (2018). Introduction to the special issue "Young People and New Geographies of Learning and Education”. Geographica Helvetica, 73, 43. doi:10.5194/gh-73-43-2018.

Beach Thomas, W. (1933, April 14). Country Life. Retrieved from The Spectator Archive: http://archive.spectator.co.uk/article/14th-april-1933/14/two-very-able-professors-of-botany-have-just$\underline{\text { forme }}$

Board of Education (1937). Suggestions for the Planning of Buildings for Public Elementary Schools. London: HMSO.

Brace, C. (2003). Envisioning England: the visual in countryside writing in the 1930s and 1940s. Landscape Research, 28, 365-382. doi:10.1080/0142639032000150121. 
Bulkeley, H. (2012) Governance and the geography of authority : modalities of authorisation and the transnational governing of climate change, Environment and planning A, 44, 2428-2444. doi:10.1068/a44678.

Bunce, M. (1994). The Countryside Ideal: Anglo-American Images of Landscape. Abingdon: Routledge.

Burke, C. (2005). Containing the school child: Architectures and pedagogies. Paedagogica Historica, 41, 489-494. doi:10.1080/00309230500165635.

Burke, C., \& Grosvenor, I. (2008). School. London: Reaktion Books.

Cartwright, .I. (2012). Informal education in compulsory schooling in the UK. In Kraftl, P. Horton, J. and Tucker, F. (eds) Critical geographies of childhood and youth. (151-68) Bristol: Policy Press.

Cloke, P., \& Jones, O. (2001). Dwelling, place, and landscape: an orchard in Somerset. Environment and Planning A, 33, 649-666. doi:10.1068/a3383.

Cosgrove, D., \& Daniels, S. (1988). (eds) The Iconography of Landscape: Essays on the symbolic representation, design and use of past environments. Cambridge: Cambridge University Press.

CPRE (1937). Wild Plant Conservation Board: The Protection of Wild Flowers (Pamphlet No. 31). London: CPRE.

CPRE (1936a). Monthly Report: August. SR CPRE (B/2/7). MERL, Reading. 
CPRE (1936b). Monthly Report: February. SR CPRE (B/2/6). MERL, Reading.

CPRE (1936c). Monthly Report: March. SR CPRE (B/2/6). MERL, Reading.

CPRE (1936d). Annual Report. SR CPRE (B/2). MERL, Reading.

CPRE (1935). Monthly Report: November. SR CPRE (B/2/6). MERL, Reading.

CPRE (c.1930s) 'After a Bluebell Raid'. SR CPRE (PH3/29). MERL, Reading.

CPRE (1926-30). Minutes of the CPRE Executive Committee. SR CPRE (A/1) . MERL, Reading.

Crawford, Lord. (1936, April 1). Correspondence from Lord Crawford to H. G. Griffin. SR CPRE (C/1/119/1). MERL, Reading.

Dehaene, M. (2005). A conservative framework for regional development: Patrick Abercrombie's interwar experiments in regional planning. Journal of Planning Education and Research, 25, 131148. doi:10.1177/0739456X04270369.

Driver, F. (1988). Moral geographies: social science and the urban environment in mid-nineteenth century England. Transactions of the Institute of British Geographers, 13, 275-287. doi:10.2307/622991. 
Elena, T., Katifori, A., Vassilakis, C., Lepouras, G., \& Halatsis, C. (2010) Historical research in archives: user methodology and supporting tools. International Journal on Digital Libraries, 11, 2536. doi:10.1007/s00799-010-0062-4.

Ferretti, F. (2016). The spatiality of geography teaching and cultures of alternative education: the ‘intuitive geographies’ of the anarchist school in Cempuis (1880-1894). Cultural Geographies, 23, 615-633. doi:10.1177/1474474015612731.

Gagen, E. A. (2004). Making America flesh: Physicality and nationhood in early twentieth-century physical education reform. Cultural geographies, 11, 417-442. doi:10.1191/1474474004eu321oa.

Griffin, H. G. (1936, May 13). Correspondence from H.G. Griffin to the Secretary of the Board of Education. SR CPRE (C/1/119/1). MERL, Reading.

Grosvenor, I. (2005). 'The Art of Seeing': Promoting Design in Education in 1930s England. Paedagogica Historica, 41, 507-534. doi:10.1080/00309230500165684.

Gruffudd, P. (1996). The countryside as educator: schools, rurality and citizenship in inter-war Wales. Journal of Historical Geography, 22, 412-423. doi:10.1006/jhge.1996.0028.

Harwood, E. (2010). England's Schools: History, architecture and adaptation. Swindon: English Heritage.

Herbert Smith, G. F. (1932, April 20). Spoils of the Countryside. Retrieved from The Times Digital Archive: http://find.galegroup.com.idpproxy.reading.ac.uk/ttda/info- 
$\underline{\text { mark.do } ? \& \text { source }=\text { gale } \& \text { prodId=TTDA\&userGroupName }=\text { rdg } \& \text { tabID=T003\&docPage }=\text { arti }-}$ cle\&searchType=BasicSearchForm \&docId=CS253044372\&type=multipage \&con$\underline{\text { tentSet}=\mathrm{LTO} \& \text { version }=1.0}$

Holloway, S. L., \& Jöns, H. (2012). Geographies of education and learning. Transactions of the Institute of British Geographers, 37, 482-488. doi:10.1111/j.1475-5661.2012.00542.x.

Hulme, T. (2015). “A Nation Depends on Its Children”: School Buildings and Citizenship in England and Wales, 1900-1939. Journal of British Studies, 54, 406-432. doi:10.1017/jbr.2015.2.

Katz, C. (2008). Cultural Geographies lecture: Childhood as spectacle: relays of anxiety and the reconfiguration of the child. cultural geographies, 15, 5-17. doi:10.1177/1474474007085773.

Kemnitz, H. (2005). Schulbau jenseits der Norm: Hans Scharouns Mädchengymnasium in Lünen. Paedagogica historica, 41, 605-625. doi:10.1080/00309230500165791.

Kozlovsky, R. (2016). The Architectures of Childhood: Children, Modern Architecture and Reconstruction in Postwar England. London: Routledge.

Kozlovsky, R. (2010). The architecture of educare: motion and emotion in postwar educational spaces. History of Education, 39, 695-712. doi:10.1080/0046760X.2010.514295.

Kraftl, P. (2013). Geographies of alternative education: Diverse learning spaces for children and young people. Bristol: Policy Press. 
Kraftl, P. (2012). Utopian promise or burdensome responsibility? A critical analysis of the UK government's Building Schools for the Future policy. Antipode, 44, 847-870. doi:10.1111/j.14678330.2011.00921.x.

Kraftl, P. (2006). Building an idea: the material construction of an ideal childhood. Transactions of the Institute of British Geographers, 31, 488-504. doi:10.1111/j.1475-5661.2006.00225.x.

Lorimer, J. (2008). Living roofs and brownfield wildlife: towards a fluid biogeography of UK nature conservation. Environment and Planning A, 40, 2042-2060. doi:10.1068/a39261.

Maddrell, A. M. (1998). Discourses of race and gender and the comparative method in geography school texts 1830-1918. Environment and Planning D: Society and Space, 16, 81-103. doi:10.1068/d160081.

Matless, D. (2016). Landscape and Englishness. (2nd ed.) London: Reaktion Books.

Matless, D. (1997). Moral geographies of English landscape. Landscape research, 22, 141-155. doi:10.1080/01426399708706505.

Matless, D. (1993). Appropriate geography: Patrick Abercrombie and the energy of the world. Journal of Design History, 6, 167-178. doi:10.1093/jdh/6.3.167.

Matless, D. (1990). Ages of English Design: Preservation, Modernism and Tales of Their History, 1926-1939. Journal of Design History, 3, 203-212. doi:10.1093/jdh/3.4.203. 
Mills, S. (2014). Geographies of education, volunteering and the lifecourse: the Woodcraft Folk in Britain (1925-75). Cultural Geographies, 23, 103-119. doi:10.1177/1474474014536855.

Mills, S. \& Kraftl, P. (2014). (eds) Informal Education, Childhood and Youth. Basingstoke: Palgrave Macmillan.

Mills, S. (2013). 'An instruction in good citizenship': scouting and the historical geographies of citizenship education. Transactions of the Institute of British Geographers, 38, 120-134. doi:10.1111/j.1475-5661.2012.00500.x.

Milne-Redhead, E. (1971). Botanical conservation in Britain, past, present and future. Watsonia, 8 , 195-203.

Murray, P. J. (2010). The Council for the Preservation of Rural England, suburbia and the politics of preservation. Prose Studies, 32, 25-37. doi:10.1080/01440351003747659.

Park, D. C., \& Coppack, P. M. (1994). The role of rural sentiment and vernacular landscapes in contriving sense of place in the city's countryside. Geografiska Annaler: Series B, Human Geography, 76, 161-172. doi:10.1080/04353684.1994.11879673.

Parrish, S. S. (2010) Rummaging/In and Out of Holds. American Literary History, 22, 289-301. doi:10.1093/alh/ajq005.

Pelham, E. H. (1936, March 2). Correspondence from E. H. Pelham to H. G. Griffin. SR CPRE (C/1/119/1). MERL, Reading. 
Ploszajska, T. (1994). Moral landscapes and manipulated spaces: gender, class and space in Victorian reformatory schools. Journal of Historical Geography, 20, 413-429. doi:10.1006/jhge.1994.1032.

Ploszajska, T. (1998). Down to earth? Geography fieldwork in English schools, 1870-1944. Environment and Planning D: Society and Space, 16, 757-774. doi:10.1068/d160757.

Reynolds, F. (2016) The Fight for Beauty: Our Path to a Better Future. London: Oneworld.

Robinson, J., \& Mills, S. (2012). Being observant and observed: Embodied citizenship training in the Home Guard and the Boy Scout Movement, 1907-1945. Journal of Historical Geography, 38, 412-423. doi:10.1016/j.jhg.2012.03.003.

Rose, G. (2000) Practising photography: an archive, a study, some photographs and a researcher. Journal of Historical Geography, 26, 555-571. doi:10.1006/jhge.2000.0247.

Savage, E. G. (1936, April 20). Correspondence from E. G. Savage to Sir Henry Richards. SR CPRE (C/1/119/1). MERL, Reading.

Seaborne, M., \& Lowe, R. (1977). The English school: It's Architecture and Organization Volume II 1870-1970. London: Routledge.

Sheail, J. (1982). Wild plants and the perception of land-use change in Britain: an historical perspective. Biological Conservation, 24, 129-146. doi:10.1016/0006-3207(82)90064-7.

Sutcliffe, J. (2009). Ecology: what next?. ECOS, 30 (3/4), 3-13. 
The Spectator (1931, May 23). Ramblers and the Countryside. Retrieved from The Spectator Archive: http://archive.spectator.co.uk/article/23rd-may-1931/6/ramblers-and-the-countryside

The Times (1933, April 12). Picking of Wild Flowers. Retrieved from The Times Digital Archive: http://find.galegroup.com.idpproxy.reading.ac.uk/ttda/info-

mark.do?\&source=gale \&prodId=TTDA\&userGroupName=rdg\&tabID=T003\&docPage=arti$\underline{\text { cle } \& \text { searchType }=\text { BasicSearchForm } \& d o c I d=C S 151988364 \& \text { type }=\text { multipage } \& \text { con }-}$ $\underline{\text { tentSet}=\text { LTO\&version }=1.0}$

Thrift, N. and Dewsbury, J. D. (2000). Dead geographies - and how to make them live. Environment and Planning D: Society and Space, 18, 411-32. doi:10.1068/d1804ed.

Woods, M. (2005). Contesting Rurality: Politics in the British Countryside. London: Routledge WPCB (1931). Report on Replies to Questionnaire. SR CPRE (H/1/57). MERL, Reading. 